\title{
Improve Students' Skills in Listening Comprehension by Using Song Based on Multimedia
}

\author{
Hariratul Jannah $^{1}$, Abdollah $^{2}$, Syahria Majid $^{3}$ \\ ${ }^{1,2}$ English LIterature, Fakultas of Letters, Universitas Muslim Indonesia \\ ${ }^{3}$ Universitas Bosowa \\ ${ }^{1}$ hariratul.jannah@umi.ac.id
}

\begin{abstract}
Abstrct
In order to improve the quality of learning English, especially listening skills, students of the English Literature Study Program and the English Language Education Study Program submitted proposals with the research title "Improving the Skill of Student Multimedia Comprehension Listening Through Multimedia-Based Song Media." The specific objectives of this study were to: 1) improve listening skills in English-speaking students of the English Language and Literature Study Program at the Faculty of Letters of UMI; 2) developing listening learning models with multimedia-based song media. This research was conducted in the UMI English Literature and English Language Education Study Program at the Faculty of Letters with targeted results as follows: 1) in one year this was a valid draft model for learning listening with multimedia-based song media. The method used in this study is action research with a population of 156 students. This study produced a draft listening comprehension model, the results of the study showed that the learning process of Listening comprehension used multimedia-based songs with subtitles of positive student responses. From the questionnaire / questionnaire / close questionnaire shows $\geq$ $75 \%$ of students respond more easily and prefer the learning process to understand meaning and understand what is heard from native speakers in learning listening comprehension. This study recommends for listening lecturers to use songs as one of the media in learning that will improve student skills
\end{abstract}

Keywords : Listening Skills, media songs, multimedia

\begin{abstract}
Abstrak
Dalam rangka meningkatkan kualitas belajar bahasa Inggris, khususnya keterampilan mendengarkan, siswa Program Studi Sastra Inggris dan Program Studi Pendidikan Bahasa Inggris mengajukan judul penelitian "Meningkatkan Keterampilan Mendengarkan Pemahaman Multimedia Siswa Melalui Media Lagu Berbasis Multimedia." Tujuan khusus dari penelitian ini adalah untuk 1) meningkatkan keterampilan mendengarkan pada siswa berbahasa Inggris dari Program Studi Bahasa dan Sastra Inggris di Fakultas Sastra UMI; 2) mengembangkan model pembelajaran menyimak dengan media lagu berbasis multimedia. Penelitian ini dilakukan di Sastra Inggris dan Program Studi Pendidikan Bahasa Inggris di Fakultas Sastra UMI dengan hasil yang ditargetkan sebagai berikut: 1) dalam satu tahun ini adalah rancangan model yang valid untuk belajar mendengarkan dengan media lagu berbasis multimedia. Metode yang digunakan dalam penelitian ini adalah penelitian tindakan dengan populasi 156 siswa. Penelitian ini menghasilkan rancangan model pemahaman menyimak, hasil penelitian menunjukkan bahwa proses pembelajaran Pemahaman Mendengarkan menggunakan lagu-lagu berbasis multimedia dengan subtitle tanggapan siswa yang positif. Dari angket / angket / tutup angket menunjukkan $\geq 75 \%$ siswa merespons lebih mudah dan lebih menyukai proses pembelajaran untuk memahami makna dan memahami apa yang didengar dari penutur asli dalam pembelajaran pemahaman menyimak. Penelitian ini merekomendasikan dosen untuk mendengarkan menggunakan lagu sebagai salah satu media dalam pembelajaran yang akan meningkatkan keterampilan siswa
\end{abstract}

Kata kunci : Islam, filsafat, bahasa, timur tengah 


\section{Introduction}

Students will be able to understand speech and conversation in English verbally and nonverbally so that four skills are needed. Listening is one of four foreign language skills (English) which is currently an obstacle for most foreign language learners in Indonesia (English foreign Language / EFL) including at the Indonesian Muslim University (UMI). Educators and instructors or lecturers try to use various methods, techniques and strategies using monotonous learning media: listen carefully, the lecturer briefly explains the meaning of the word, then checks the answers, then is given the task, eventually the students feel bored. Students of the English Literature Study Program and the English Language Education Study Program at the Faculty of Literature at the University of Indonesia with learning conditions that are less attractive and less attractive in a methodological manner must be given a learning model in using learning media with more varied types of media. Listening is one skill that requires creativity in the learning process because speech from speakers will influence and be recorded directly into the human brain of terms, but not all humans can immediately recall what has been heard with various causal factors.

Songs as authentic listening material are sung and with varying tones and genres of music become one of the media that can improve students' skills in learning English. The song in listening learning includes understanding the meaning of words, phrases, clauses, sentences and complete discourse relations.

\section{Listening Comprehension}

Listening comprehension is a complex multidimensional process in Indonesia where many factors come into play, interactive models of textual understanding argue that students use previous contextual knowledge (top-down processes) as well as their L2 knowledge (bottom-up process). Thus, both text processing models are needed if we want to see the understanding of text as an interactive process. In fashion, Rost (2002) explains how these two processes operate on listeners as follows: Speech perception and word recognition are 'bottom-up' processes in listening: they provide 'data' for understanding. If the listener doesn't recognize enough this bottom-up signal for processing speech in real time, he will rely more on 'top-down' processing expectations and semantic generalizations. (Dare in the original, p. 96). Rost (2002) also provides a definition of understanding text that integrates both text processing models and which summarizes these discussions with both complex processes

\section{Multimedia}

Multimedia in this research is like CAI (Computer Assisted Instruction), compact disk (CD) interactive learning multimedia, and web (web based learning).

Multimedia is taken from multi words and media. Multi means many and media means media or intermediaries. Multimedia is a combination of several elements, namely text, graphics, sound, video and animation that produce amazing presentations. Multimedia also has high interactive communication. For computer users, multimedia can be interpreted as computer information that can be presented through audio or video, text, graphics and animation. Here can be described that multimedia is a combination of data or media to convey information so that information is presented more interesting.

"Multimedia is a combination of computer and video (Rosch, 1996) or Multimedia in general is a combination of three elements, namely sound, image and text (McCormick 1996) or Multimedia is a combination of at least two input or output media from data, media can be audio (sound, music), animation, video, text, graphics and images (Turban et al., 2002) or Multimedia is a tool that can create dynamic and interactive presentations that combine text, graphics, animation, audio and video images (Robin and Linda, 2001). Multimedia is the use of computers to create and combine text, graphics, audio, moving images (video and animation) by combining links that allow users to navigate, interact, create and communicate.

This definition contains four essential components of multimedia. First, there must be a computer that coordinates what is seen and heard. Secondly, there must be a link 
that connects the user with information. Third, there must be a navigation tool that helps users explore information networks that are interconnected. Fourth, multimedia provides a place for users to collect, process, and communicate information with ideas. If one component does not exist, it is not multimedia in the broadest sense of its name. For example, if there is no computer to interact with, then it's called mixed media, not multimedia. If there is no navigation tool that allows to choose the course of an action, then it's called a film, not multimedia. Likewise, we do not have the space to create and contribute our own ideas, then the names of televisions, not multimedia. From some of the definitions above, multimedia is online (internet) and multimedia is offline (traditional). "

Multimedia is the use of computers to present and combine text, sound, images, animation, audio and video with tools and connections so that users can navigate, interact, work and communicate. Multimedia is often used in the world of informatics. Apart from the world of informatics, Multimedia is also adopted by the world of games, and also for creating websites.

Multimedia is an interconnected combination ranging from digitally manipulated text, photos and images, animations and videos (Vaughan, 2011: 1). According to Hofstetter (2001: 2) describing multimedia is the implementation of computer use in presenting and combining text, images, sound and video with interfaces that allow users to interact with the multimedia system

According to Vaughan (2011: 1) the main elements of multimedia are five types, namely:

1. Text

Text is used for thousands of years by humans to communicate. But a word has many meanings so that the words used must be short, solid and precise so that the message and data can be delivered properly. Text is generally used to design titles, menus and buttons (Vaughan, 2011, p.20)

2. Sound

The use of sound in multimedia can produce one difference from the results of ordinary multimedia presentations with professional multimedia.
According to Vaughan (2011: 104) there are two kinds of sounds that can be used in multimedia:

Digital audio is the result of the conversion of sound waves stored in information in the form of bits or bytes. this process is called digitizing. The quality of the digitizing results depends on how often the sample is taken or the sampling rate and how many numbers are used to stream each sample or commonly called bithdept (Vaughan, 2011, p. 106).

2. Midi stands for Musical Instrument digital Interface is the type of sound that is most easily implemented in a multimedia. MIDI itself is a form of conversion of sounds stored in numeric form (Vaughan, 2011, p.134)

Picture. According to Vaughan, there are 2 types of images that can be produced by computers, namely:

a. Bitmap is an image formed from a matrix consisting of color dots. Color variations in bitmap images are determined by the bitmap displayed, where n-bit bitmap images have 2 kinds of colors (Vaughn, 2011, p.71-72).

Vector drawing is an image that is produced from the calculation of Carthesian coordinates by a computer which is commonly used to produce line, square, circle, oval and polygon shapes (Vaughan, 2011, p.80).

\section{Video}

The use of video in a percentage of multimedia can be a medium for delivering messages and information that is very effective. According to Vaughan in a multimedia project, the use of video can convey messages to users effectively and users easily remember what they have witnessed (2011, p.164). According to Datsbatz (2003, p.62) video is a subtle combination of moving and sound images.

\section{Animation}

Animation is the main source of a dynamic multimedia action in a multimedia presentation. Animation is also used to help presentations such as slide and other transition effects

\section{Method}


In this research. Learning methods are easier and more interesting with multimedia -based song media in improving students' skills to speak English, especially Listening skills.

\section{Learing Multimedia}

The definition of multimedia learning is divided into two, namely the definition before the 1980s and the definition after the $1980 \mathrm{~s}$. Before the $1980 \mathrm{~s}$ or in the $60 \mathrm{~s}$, according to Barker \& Tucker, 1990 (Sunaryo Soenarto, 2005: 116), multimedia was interpreted as a collection of various different media equipment used for presentations. In this sense multimedia is interpreted as a variety of media used for the presentation of subject matter, for example the use of wall charts or graphs made on paperboard affixed to the wall.

Tan Seng Chee \& Angela F. L. Wong (2003: 217) stated that multimedia traditionally refers to the use of several media, while multimedia in today's age refers to the combined use of several media in the presentation of learning through computers.

According to Vaughan (2011: 1) the main elements of multimedia are five types, namely:

1. Text, 2. Sound, 3. Picture, 4. Video, 5. Animation

The research method used in this study is an action research action using two namely; cycle 1 and cycle 2 . For the method of discussing the research used is quantitative descriptive. Descriptive is meant by using a questionnaire and observing the activities of developing learning methods. The quantitative method used is measuring the feasibility of learning devices.

This research was conducted at semester III level, S1 Department of English Language Education, Faculty of Letters and English Literature Study Program were 58 students from a population of 156 third semester students. The reason for this research is because they often meet students with various complaints both the acquisition of learning outcomes and the quality of learning listening that has been carried out. Some of the students who had attended listening courses had low results, and felt they were not interested because the listening subjects were considered too difficult so that the learning outcomes obtained values also became low. The implementation of this study was conducted from September 2017 to April 2018. The data sources (instruments) in this study were as follows: a.) A written test of listening skills comprehension especially presentations in the form of student worksheets for pre-tests and posttests. b) The results of the questionnaire distributed to students to find out their responses or opinions on learning comprehension using English-language and multimediabased songs in this study. c) Interviews by collaborators to find out the impressions and opinions of students during the study. This data collection technique also aims to find out the learning needs of students, especially in speaking, writing and presentation activities after listening to songs that have been played both through audio and displayed on video.

\section{Data analysis}

a. Understanding of student listening is assessed based on aspects of the assessment rubric that cover aspects of content, understanding, accuracy, and effort. Then the results were analyzed descriptively comparatively by comparing test scores between cycles and performance indicators.

b. Questionnaires were given before and after the actions in cycles I and II. The results were analyzed descriptively.

c. The results of the interviews were also analyzed descriptively.

d. The results of observations by collaborators were analyzed descriptively to determine the activity of attraction or the condition of students towards the subjects of listening comprehension during the learning process in the study.

Research Procedure a. Preparation At this preparation stage, researchers conducted several activities such as searching for references relating to strategies for using English Songs with English Subtitles, listening skills, listening comprehension, and multimedia references as well as class caction research / action research. b. Acting c. Observation / Evaluation 
Observation or evaluation on the development of student abilities is carried out in each phase of treatment. The data are analyzed descriptively and overall evaluated with input from the results of data analysis. d. Reflection: After getting a detailed description of the successes and obstacles experienced in implementing an English song strategy with English Subtitle this time, the researcher continues the research by repeating from the planning stage. If the results obtained in the first cycle are not satisfactory, the researcher will make a revision or modification to continue the next cycle

The flow chart of this research can be seen in Figure 1.

Figure 1. Research Flow Char.

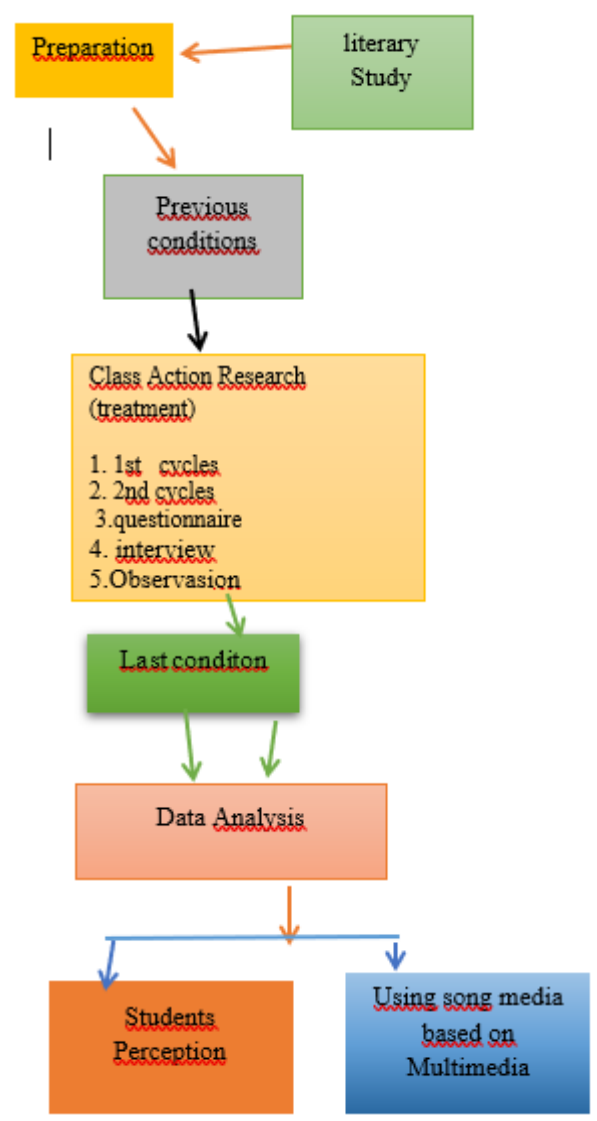

\section{Results and Discussion}

People imitate by listening, those who cannot listen will almost certainly not be able to imitate. Hearing is closely related to pronunciation, correct or not pronunciation depends on whether or not it is heard. From the number of questions 27 questions in the questionnaire given, $80 \%$ or equivalent to 24 questions gave linear results with the results of the tests. What is meant linearly in this case is that what is the opinion or the respondent's answer to the questionnaire results are balanced with the results of the test. 27 questions are classified into three characteristics to get the desired answer. The first question relates to the hobby of students in listening to music, then the second characteristic of the question relates to the function of the song in the process of learning English in particular, and the latter characteristics relate to the effectiveness of the song as a medium for learning pronunciation. The types of questions given are open questions, meaning that students may answer according to their wishes, even though some questions only need to be answered with yes or no. Examples of closed questions are like; "Do you like listening to music / songs?", While open questions are asked for example; In your opinion, what is difficult about learning pronunciation / pronunciation? ". These two questions do have different characteristics, the reason for using questions like this is to get broader answers, not only limiting respondents to answer yes / no, so that there is more input for the respondents.

From the first song, the number of vocabulary given amounted to 30 , the highest answer amounting to 26, while the lowest number numbered 10 . The highest number of students answered the test 19 with the right answer. These results generally still show students' unpreparedness in facing the test, both from the ability to answer in writing and the ability of students to share their concentration by listening to songs. There are still 2 respondents who answered 10 questions correctly. This number is actually still very unsatisfactory if you see the song used in this test, the tempo / rhythm is slow, the lyrics are simple, and also the duration is quite long. The respondents were very enthusiastic in listening to the song, but the results have not shown a positive response according to the author for this activity.

The second test uses Amazing Day songs. The song is very slow in its rhythm, the verses are more varied, in terms of literature is very beautiful, in the sense that not 
all of them can be interpreted textually, so that this song is very interesting to listen to, the feeling that is generated to the listener makes it relaxed. The results of the second test increased significantly, the number of questions there was 38, the highest answer was 35 , while the lowest number was 20 . Variants of the number of correct answers also amounted to 5, meaning that the correct level of answers consisted of 5 groups.

Respondents answered that the second song was easier than the first, although the word variant was more difficult than the one used in the first test, only the rhythm was slower. This could be what makes students consider this song easier, seen from the word variant is more difficult, but the slow rhythm makes them have a longer chance to record the poem into their memory. The 45 questions given in the third test were able to be answered by the students quite well, the highest number of correct answers was 43, and the lowest was 24 . This number significantly illustrates that listening habits will help students answer questions, their psychological condition will be calmer, more prepared, and also able to provide a better response by the more often they listen to songs. This song has the longest verse compared to the other three songs, but the number of answers is the highest. As stated above, students are better prepared for this third test, besides they often listen to this song in the Intensive Course.

This last cycle provides 35 questions, less than the previous two tests, with the consideration that this song has a fast rhythm, and also verses that have more vocabulary variants. The level of difference or the group that answers the questions correctly becomes fewer, namely 4 groups, with the number that answers all ten students correctly, correctly answers 30 out of 5 students, five students correctly answer 28 items from all questions, and the most answers lower than 35 questions is 25 . If seen from the percentage, this fourth test shows the most significant results. The difference between one group and another group is only slightly different, so that it can be interpreted the level of understanding of students shows positive changes.
Most of the students of English language and literature study program and Study Program of English Language Faculty of the Faculty of Letters are students who have quite good communication skills, but that ability is still limited by interpersonal communication, not public communication. Their communication in English is only limited in class, while outside the classroom they still use Indonesian or Mother tongue. In practice, they are only able to communicate verbally in a simple way, such as answering short questions, conveying simple intentions, and some brief types of dialogue. On the other hand, if examined in more detail, their communication has not been said to be appropriate when their pronunciation is not appropriate. They are contextually able to communicate, but they are not fully correct in language. People are said to speak well and correctly if they are able to recite clearly and are also able to express their opinions coherently.

Basically, student comprehension/ comprehension abilities are influenced by hearing / listening, and pronunciation exercises. The habit of speaking will affect flexibility in speaking according to English. As is known, language is a matter of habit, so the more practice it is, the easier it is for someone to learn languages, as well as the formula for listening, the more often they listen, the easier it is to recognize their vocabulary and speech. From the tests given first to the last, it is still clearly seen that those who are reluctant to communicate verbally (quiet) have relatively lower utter ability than those who are active. Those who look comfortable and enjoy listening to songs have abilities that look good and right, besides of course they practice in class.

Before being given treatment and tests, a questionnaire was given to get support for hypothesis data. From the first meeting it was concluded that many of them could not pronounce English sentences correctly. From the number of questions 27 questions in the questionnaire were given, $85 \%$ or equivalent to 24 questions gave linear results with the results of the tests. What is meant linearly in this case is that the respondents' opinions or answers to the questionnaire results are balanced. Of all the tests given, the results generally show pro- 
gress. From the process, students are able to recognize and make songs as learning media, not merely as entertainment. They are able to analyze how the message of a song through the poem, and also be able to find the equivalent of several words that mean the same. In writing, the ability of students to learn the vocabulary of the poem is far higher than the ability of pronunciation.

The list of words they can correctly mention is always higher than the list of pronunciation they can say. Even so, after a number of meetings, the level of student validity in saying increased. They also learn from pronunciation drill other than checking and making sure of the song being played

The habit of saying will affect flexibility in speaking in accordance with English. As is known, language is a matter of habit, so the more practice it is, the easier it is for someone to learn languages, as well as the formula for listening, the more often they listen, the easier it is to recognize their vocabulary and speech. The choice of songs is an important point when we talk about the purpose of teaching, teaching should provide an educative side, not just entertainment so that the goal of creating a quality generation can be realized sustainably

\section{References}

Cresswell, John. W. 1994. Research Design Qualitative and Quantitative. California: Sage Publication Approaches.

Fonseca-Mora, M.C., Toscano-Fuentes, C., \& Wermke, K. (2011).Melodies that help:The relation between lauguage aptitude and musical intelligence.Anglistik International Journal of English Studies, 22(1), 101-118.

Harmer, Jeremy. 2001. The Practice of English Language Teaching. London: Longman

Harmer, Jeremy. 2007. How to Teach English. London: Pearson Longman

Joyce, Bruce, et. al. 2000. Models of Teaching. Boston: A Pearson Education Company

Jack C. Richards.2000.Teaching Listening and Speking from theory to Practice.Cambridge University Press
Krashen, Stephen D. 1983. Principles and practice in second language acquisition. Oxford: Pergamon Press.

Millington,N.T (2011).Using Songs effectively to teach English to young learners. Language Education in Asia.Vol.2.no.1.134-141.14 October 2017

Rost M. (2002). Teaching and Researching Listening. Longman: Pearson Education.

Vaughan,Tay. 2011. Making it works.eight edition.McGrow Hill.eBook.retrieve and accesses on November 2012 